\author{
KROTOFIL MACIEJ, \\ Nicolaus Copernicus University in Toruń (Toruń, Poland) \\ e-mail:makr@umk.pl,oRCID 0000-0002-6691-5532
}

SRIBNYAK IHOR,

Borys Grinchenko Kyiv University (Kyiv, Ukraine)

e-mail: i.sribniak@kubg.edu.ua,ORCID0000-0001-9750-4958

SRIBNIAK MILANA,

Taras Shevchenko National University of Kyiv (Kyiv, Ukraine)

e-mail: milana.sribniak@gmail.com, ORCID 0000-0003-1353-3001

\title{
ACTIVITY OF THE UNR MILITARY AND SANITARY MISSION ON PRISONERS' OF WAR AFFAIRS IN GERMANY (1919)
}

The relevance of the article lies in the necessity to discover major aspects of the UNR Military and Sanitary Mission's activity on prisoners of war (POWs) in Germany. The Mission's crucial task was to facilitate their repatriation. It should be noted that the main obstacle for Ukrainian POWs' transportation was based on the development of the destructive political processes on the territory of former Russian empire, particularly due to the consolidation of power in the hands of Bolsheviks in Petrograd. The study is to determine the features of the cooperation between the Mission and Ukrainian POWs' camp communities, as well as the quantity and characteristics of the humanitarian assistance provided to POWs. The research identifies that the Mission succeeded in improving living conditions for POWs at camps through sending food supplies, clothes and shoes. In addition, it cared for POWs' moral needs by implementing courses, lessons, theatrical plays and sending Ukrainian periodicals and books to the camps. What is more, the Mission was responsible for the sanitary care, especially in regard to sending medicaments and medical staff. The mission also developed the ways and logistics of POWs' repatriation process as well. The study's novelty lies in in a comprehensive research of the Mission's activity which resulted in organizing, in SeptemberOctober 1919, the transportation of small POWs group to Czechoslovakia with Ukraine as a final destination. Nonetheless, the negotiations regarding a massive repatriation were not successful and, thus, a considerable part of POWs stayed in camps until May 1920. Despite these events, the Mission's activity had positive consequences for most Ukrainian POWs, particularly organizing their national life in camps.

Key words: Ukrainian POWs; Military and Sanitary Mission; repatriation; camp; Entente; Germany.

\section{Introduction}

Because, in early 1919, a large number of Ukrainian POWs (approximately 300,000 , according to the German military ministry) ${ }^{1}$ remained on the German territory, the diplomatic corpus of the Ukrainian National Republic (UNR) Directory undertook a set of measures designed to make their lives abroad easier while they were waiting for return home. At the same time, the most urgent task of the UNR government was to organize an immediate repatriation, which was desired by the POWs the most. In the meantime, as well as before, immediate transportation of POWs to their home country could have caused the collapse of German economy, which heavily relied on the exploitation of hundreds of thousands of Ukrainian and Russian POWs. Besides, Germany could not even provide enough railway capacity and cover the costs of transferring of heaps of POWs to German borders due to the financial deficiency of the country' treasury in the beginning of 1919.

Meanwhile, Ukrainian POWs overall did not want to

1 Центральний державний історичний архів України, м. Львів (ЦДІА України, м. Львів), Fond 368 List 1 File 78 Page 27. [Central State Historical Archive of Ukraine in Lviv (CSHAU in Lviv)] consider the economical difficulties suffered by the former empire. They expected assistance from the UNR, and a considerable number of captured soldiers sincerely endeavored to serve the independent Ukraine. In turn, the Directory of UNR relied on in their return as the way to reinforce armed services of the republic, which was essential for the facilitation of efficient defense against Bolsheviks' attacks. Consequently, the UNR diplomacy had to act urgently to organize repatriation of Ukrainian captured soldiers. Unfortunately, these plans were hindered by some steps of the Entente occupation government in Germany, particularly the establishment in January 1919 of a special commission responsible for the evacuation of all the POWs of former Russian empire's army (including Ukrainians). Regrettably, the first directive of this commission was the prohibition of Ukrainian and Russian POWs' dispatching to the homeland because of revolutionary events in Russia.

\section{Analysis of studies and publications}

Scientific research on the problem of Ukrainian POWs' repatriation from the territory of Central Powers intensified in the early 1990s, when researchers of the Ukrainian diplomatic service, in a sporadic way, shed some light on 
the organization process of them returning home (Vyedyeneyev, Tabachnyk 1992-1993; Vyedyenyeyev 1996; Vyedyenyeyev, Budkov 2006).

Research on this problem saw qualitative changes with the publishment of I. Sribniak's monograph that includes a section called "The activity of Ukrainian diplomatic and military and sanitary missions on repatriation of Ukrainian POWs (1918-1920)" (1999a), which is devoted entirely to discussing this topic. Besides, a number of his other publications (1999b; 2003; 2009), including the ones he co-authored (Sribnyak, Sribniak 2016; 2019a; 2019b), concern the specific question of Ukrainian POW ' repatriation from the territory of Central Powers.

The processes of repatriation of Ukrainian POWs and interned soldiers from Ukraine have also been among the scientific interests of V. Solovieva $(2004 ; 2006)$. Within her research topic, she also concentrated on their efforts in consular services devoted to organizing a transfer of the aforementioned categories of soldiers. This topic has also been studied by other researchers, who significantly expanded our view of the specific features of Ukrainian POWs' repatriation (Zhvanko 1999; Zhvanko 2014).

\section{Purpose}

The aim of this article is to showcase the activity of the UNR Military and Sanitary Mission for the affairs of Ukrainian POWs in Germany in 1919. To achieve it, the article draws on a wide variety of archival sources and materials of periodical press.

\section{Methods}

The methodology is based on the appliance of problematic, chronological, systematically historical, comparatively retrospective and analytical methods of scientific research; their combination allows to draw an integrated picture of the main directions of Ukrainian diplomacy's activity in Germany throughout 1919 .

\section{Results and Discussion}

Nonetheless, this decision did not influence the eagerness of the UNR Directory to actively commence the process of repatriation their fellow POWs. Thus, on 10 May 1919 , the decree of the head of "Permanent commission on prisoners of war" Myronovych (in accordance with the order of the Chief Otaman of UNR Army Symon Petlura) provided a pathway for the first changes in personnel of leadership of Military and Sanitary Mission in Germany. First sergeant Dr. Kostiantyn Voyevidka was appointed as the head of the mission and was entrusted to establish the mission "with that personnel which is considered necessary in order to develop the affair properly"2. In addition, according to the decree of the head of the Permanent commission Voyevidka, two doctors (Mychkovskyi and Murzin) became the members of medical personnel of the mission with the approval of the Chief Military and Sanitary Administration of UNR Military Ministry ${ }^{3}$.

The evidence of the Directory's significant attention to

\footnotetext{
${ }^{2}$ Wojskowe Biuro Historyczne (WBH), Centralne Archiwum Wojskowe (CAW), Zespól Akt "Sprzymierzona Armia Ukraińska" (SAU), sygn. I.380.1.46, k.1-2 [Military Historical Office (WBH), Central Military Archives (CAW)]

Центральний державний архів вищих органів влади та управління України (ЦДАВО України), Fond 3696 List 2 File 305 Page 13. [Central State Archive of Supreme Bodies of Power and Government of Ukraine]

${ }^{3}$ ЦДАВО України, Fond 3696 List 2 File 305 Page 13. [Central State Archive of Supreme Bodies of Power and Government of Ukraine]
}

prompt resumption of Military and Sanitary Mission's activity was the mission being funded for 1 million karbovantsiv; besides, the Military Ministry of Germany and its department of POWs were informed about changes in the executive personnel of the mission. Simultaneously, the Directory defined the main streams of the Mission's expenses; the funds had to be allocated to "the foundation of stockade and food facilities, elaboration of routes for captured soldiers' return to the motherland, development of widespread informative and educational work at camps" 4 .

Paradoxically, archival documents contain the fact that on 20 January 1919, Petlura's adjutant, sotnik Fedir Kryshynskyi delivered to Berlin another order from the Chief Otaman of UNR Army. According to this document, ensign Mykola Trezvinskyi was appointed as the new head of the Military and Sanitary Mission. On that very day, the council of the Mission's members accepted the decision; at the same time, it was decided that K. Voyevidka would preside as a chairman until the arrival of the newly appointed head. Simultaneously, members of the council condemned such a practice of appointment and dismissal from the position, considering this practice "unethical, destructive for the new Republic (the text was originally underlined - Authors), which is not common even in bureaucratic, monarchic states" and, in their opinion, discredited the UNR government ${ }^{5}$.

In the end, there is every reason to believe that the latter order did not become valid or was retracted because $\mathrm{K}$. Voyevidka continued to serve as the head of the mission until the end of February 19206; Dr. Andrii Zhuravel became his deputy as well as the mission's senior doctor (previously he served as a doctor in a military hospital in Kyiv). Dr Honcharenko was appointed as the head of the medical and sanitary department and junior doctor; ensigns M. Trezvinskyi and Fedir Luhovenko were appointed to the positions of chief administrator (secretary) and treasurer respectively ${ }^{7}$. The mission's structure saw the establishment of three departments, namely cultural and educational (headed by V. Simovych), administrative (headed by M. Parashchuk), information and statistics (headed by the former POW of Ukrainian camp Rastatt H. Petrenko) ${ }^{8}$.

The tasks of the mission included the representation of Ukrainian POW s' interests in front of German and Entente authorities, providing aid and moral support for this category of Ukrainian citizens as well as organizing their return to the homeland. In order to implement this purpose, the mission strived for facilitating POWs' unity through Ukrainian communities, particularly via practical actions for making the stay easier (e.g. financial and humanitarian aid, such as food, clothes and shoes), caring about spiritual needs (organizing courses, lessons, theatrical performances; sending Ukrainian periodicals, books and libraries) as well as designing the ways for repatriation and its logistics ${ }^{9}$. The mission also provided sanitary aid to captured

${ }_{4}^{4}$ ЦДАВО України, Fond 3696 List 2 File 305 Page 14. [Central State Archive of Supreme Bodies of Power and Government of Ukraine]

${ }^{5}$ WBH, CAW, Zespól Akt "SAU", sygn. I.380.1.46. [Military Historical Office (WBH), Central Military Archives (CAW)]

6 ЦДАВО України, Fond 3192 List 2 File 2 Page 7. [Central State Archive of Supreme Bodies of Power and Government of Ukraine] ${ }^{7}$ WBH, CAW, Zespól Akt "SAU", sygn. I.380.1.46.8 [Military Historical Office (WBH), Central Military Archives (CAW)]

8 ЦДАВО України, Fond 1078 List 2 File 20 Page 134. [Central State Archive of Supreme Bodies of Power and Government of Ukraine]

9 Ukrayinska Vijskova Misiya dlya sprav ukrayinskykh polonenykh u Nimechchyni. Shlyah: Illustrated appendix. 21 June. 1919. Part 2 
individuals as well through sending medication and medical staff whose activity of was guided by a separate instruction ${ }^{10}$

There were considerable difficulties during the first stages of the activity of the Military and Sanitary Mission because of Entente representatives' unwillingness to provide the mission with at least minimal amount of aid in Germany to implement Ukrainian POWs' repatriation. German authorities held a similar position, and K. Voyevidka mentioned this fact in his letter (№392, dated 28 February 1919) to the head of the Military and Sanitary Mission in Austria that all the actions of the mission "to push things along" brought about limited result. Nevertheless, the Military and Sanitary Mission in Germany equipped small groups of repatriated Ukrainians, who returned home through the Czechoslovak Republic, with necessary materials ${ }^{11}$.

In order to get all the information required for its activity, the Military and Sanitary Mission in Germany addressed the POWs and called for the formation of lists of all Ukrainians in camps in February 1919, supporting it with the correspondence with Ukrainian communities regarding this inquiry. According to its estimation, in the beginning of March 1919 there were 11248 Ukrainian POWs (here and afterwards - the author's estimation) who were members of Ukrainian organizations at multinational camps (Celle, Cottbus, Soltau, Kassel, Marderburg, Gardelegen, Rubelen, Frankfurt (Oder), Hameln, Sprottau, Puchheim, Stargard) ${ }^{12}$.

The Military and Sanitary Mission in Germany coordinated its activity with the Ukrainian Red Cross mission, which consisted of doctor I. Holodnyi (head), O. Chubynski, doctor V. Zelynskyi, doctor A. Halyn and 45 representatives of medical personnel and technical staff (doctors, sisters of mercy, medical assistants) who arrived to Germany on 20 March 1919. They were directly responsible for caring after sick Ukrainians at camps, escorting POWs during their transportation to home, establishing food and firstaid posts on transport route as well as servicing hospital cars. The mission was accompanied by six railcars with flour, salo and other products, which had to be delivered to sick POWs at infirmary as well as inventory and linen for two new infirmaries ${ }^{13}$.

Such steps of the UNR government allowed limiting negative consequences of withholding the process of repatriation in January 1919. POWs blamed Ukrainian diplomatic representatives and the Military and Sanitary Mission in the first place. Due to such public sentiment, first endeavours of the mission to begin cultural and educational work met considerable opposition from the camp prisoners' side. Taking into consideration the importance of truthful and objective informing of "POWs and non-POWs Ukrainians about the events in Ukraine, the activity of Ukrainian government in order to support readers in their sorry condition", the mission began publishing the newspaper "Shlyah" ("Path") from 26 February 1919 according to Ukrainian government's order ${ }^{14}$. The magazine was published twice a week with a considerable circulation of

${ }^{10}$ ЦДАВО України, Fond 3696 List 2 File 305 Page 100-103. [Centra State Archive of Supreme Bodies of Power and Government of Ukraine]

11 ЦДАВО України, Fond 3192 List 2 File 5 Page 2-3. [Central State Archive of Supreme Bodies of Power and Government of Ukraine] 12 Skilko ukrayinciv probuvaye shhe $\mathrm{v}$ poloni po mishanykh taborax Shlyah: Illustrated appendix. 5 March. 1919. Part 3. (In Ukrainian). 13 Shlyah: Illustrated appendix. 29 March. 1919. Part 5; 14 June. 1919. Part 30; 30 July. 1919. Part 3 (Misiya Ukrayinskogo Chervonogo Khresta)

14 Shlyah: Illustrated appendix. 26 February. 1919. Part 1.
5000 copies $^{15}$, which became possible thanks to the influx of financing from the UNR Embassy in Berlin and Mission's treasury (32500 deutschemarks on a monthly basis) ${ }^{16}$. The committee of the Military and Sanitary Mission in Germany headed by editor-in-chief $Z$. Kuzelya edited the magazine.

Because many Ukrainians stayed in multinational camps in Germany, "Shlyah" published articles and messages from various camps, particularly those where Ukrainian organizations and groups had already existed ${ }^{17}$. The editorial board's aim was also to publish all the orders by the UNR government and Entente which led the process of POWs' transportation. The magazine's editors actively held correspondence with Ukrainian organizations from a variety of camps and, in some time, their actions received positive feedback from camp communities. In particular, the POWs' letter from the camp Bayreuth (Bareid in German) mentions that "'Shlyah" drifts in the hearts of the fiveyear sufferers an incredible delightfulness, and even pure Russian nationalists read the Ukrainian newspaper"18.

Throughout January-March 1919 the Military and Sanitary Mission in Germany addressed the head of the Entente commission on POWs' affairs general Juwart and the chief of the French military mission general Anri Dupont through letters in order to draw their attention toward Ukrainian POW to jumpstart their transportation to the motherland. Nonetheless, Entente representative did not rush with approval of a decision necessary for the UNR, and only on 11 April 1919 general Juwart notified Ukrainians about the possibility of Ukrainian POWs' transportation through Czechoslovakia ${ }^{19}$. After that, Deputy Head of the Mission doctor A. Zhuravel immediately departed to Prague for negotiations with the Czech government, where on 8 May 1919 he was hosted by the Chief of the General Staff of Czechoslovakian army general M. Pellet who informed that the transportation is impossible due to the interdiction of the head of the French military mission Marshall Ferdinand Foch, taking into account the unstable political and military situation in Galicia and Hungary.

On 13 May 1919, the Military and Sanitary Mission in Germany contacted the chief of the British military mission in Germany, general Malcolm (the new Entente commission's head) and general A. Dupont with the inquiry to cancel the forbiddance on Ukrainian POWs' transportation. Meanwhile, General J. Haller's army occupied Galicia and, as a consequence, the issue of repatriation through the territory of Galicia became inapplicable. Thereby, the UNR Military and Sanitary Mission took further actions in solving this problem. On 19 May 1919, answering mission's inquiries, general Malcolm addressed Ukrainian POWs with the announcement which proclaimed that Entente did everything possible to return them home as soon as possible ${ }^{20}$. This announcement, as well as the arrival of special Entente commissions to the camps to control food supplies, helped soothe captives' disappointment with the delays of repatriation.

15 Shlyah: Illustrated appendix. 21 June. 1919. Part 2 (Ukrayinska Vijskova Misiya dlia sprav ukrainskykh polonenykh u Nimechchyni). ${ }^{16}$ ЦДАВО України, Fond 3696 List 2 File 305 Pages 18, 30. [Central State Archive of Supreme Bodies of Power and Government of Ukraine]

17 Shlyah: Illustrated appendix. 5 April. 1919. Part 11 (Z zhyttia polonenykh u Nimechchyni)

18 Shlyah: Illustrated appendix. 8 October. 1919. Part 63

19 ЦДАВО України, Fond 1084 List 1 File 7 Pages 320. [Central

State Archive of Supreme Bodies of Power and Government of Ukraine]

20 Shlyah: Illustrated appendix. 5 June. 1919. Part 33. 
In the meantime, the mission's activity was considerably complicated with various obstacles from German side as well as the activation of the propaganda which spread by Denikin's emissaries and Bolshevik agents who started powerful anti-Ukrainian propaganda at camps. The Military and Sanitary Mission's announcement resulted in vigorous protest from Ukrainian organizations concerning Russian officers' endeavours to implement registering those willing to join Denikin's Volunteer Army ${ }^{21}$. In June 1919, due to Mission's inquiries, the Entente Inter-Allied Commission was forced to distance itself from Russian officers' actions, at least formally. In particular the letter, signed by the general Malcolm and published by "Shlyah", proclaimed that "the Inter-Allied Commission has never approved any register of Ukrainian POWs to any volunteer army and that no Russian officer has the right to do so"22.

In turn, the Mission's endeavours to "save [Ukrainian POWs] faster from the influence of Bolshevik agitators at German camps" ${ }^{23}$ were not always efficient because in summer 1919, the POW ' transportation through the territory of Czechoslovakia was impossible due to the military conflict between the UNR and Poland. The Mission had planned to guarantee POWs' moving through German ports to Odesa, although this way also proved to be non-functional because of the considerable expenses and the danger of a forced Ukrainians' mobilization to the Volunteer Army.

At that time (June 1919), an estimated 19 members (including 4 women) comprised the Mission, and the membership significantly increased up to 30 people in a month. The Mission continued to provide financial assistance to Ukrainian POWs, particularly at the camps where Ukrainian organizations had already existed. According to statistics of June 1919, 32 organizations received such help, and, among these organizations, "18 camp communities and 7 committees, which represent 45000 Ukrainian POWs, have stronger connections with the Mission" 24

Apart from purchase of products, linen and medicaments, the Mission also continued to assist Ukrainian POWs and morally support them by publishing the newspaper "Shlyah" and spreading Ukrainian books and textbooks in camps, spending 35500 deutschemarks monthly. The direct financial support of Ukrainian organizations reached 41800 Deutschemarks and, additionally, 5000 Deutschemarks for camp theatres in Wetzlar, Hameln, Zerbst, Sagan and Soltau ${ }^{25}$. Furthermore, the Mission provided talented Ukrainians with financial assistance (POWs Chabaniuk, Kovtunivskiy, Bilskyi and Kovalenko) for studying in a conservatory, art school or chemistry institutes in various German cities. The Mission tried to make arrangements for a permanent governmental scholarship through the letter, addressed to the chief of the Main Directorate of the General Staff of the UNR Army, dated 22 October $1919^{26}$

21 Shlyah: Illustrated appendix. 7 June. 1919. Part 27

22 Shlyah: Illustrated appendix. 5 June. 1919. Part 33 (Lyst Mizhsoyuznyczkoyi Komisiyi).

${ }^{23}$ ЦДІА України, м. Львів, Fond 368 List 1 File 78 Page 5. [Central State Historical Archive of Ukraine in Lviv (CSHAU in Lviv)]

24 ЦДАВО України, Fond 3696 List 2 File 305 Pages 23. [Central State Archive of Supreme Bodies of Power and Government of Ukraine]

${ }^{25}$ ЦДАВО України, Fond 3696 List 2 File 305 Page 18. [Central State Archive of Supreme Bodies of Power and Government of Ukraine]

26 ЦДАВО України, Fond 3696 List 2 File 305 Pages 18, 104. [Central State Archive of Supreme Bodies of Power and Government of Ukraine]
The beginning of June 1919 was marked by joint arrangements of the Ukrainian Red Cross together with the Military and Sanitary Mission in Germany in Berlin. A special "stanitsa" [temporary shelter for POWs as a part of the repatriation process - Authors] was established, particularly for those Ukrainians who were sent to the capital by Ukrainian organizations. There they could receive food and place to sleep for two days ${ }^{27}$. The medical aspect of activity prospered thanks to the establishment of infirmaries to which the Ukrainian Red Cross sent doctors. According to the statistics of November 1919, 1) P. Klynytskiy and Hajvoronskiy arrived to Salzwedel; 2) A. Iskra to Sturgart; 3) Syhovachenko to Cottbus; 4) Mychkovskiy to Gardelegen; 5) Kliuchevskiy to Celle; 6) Bryzgun to Neuhammer; 7) Sharovskiy to Zerbst; 8) Tsheglov to Hameln; 9) Kluchko to Zoltav and 10) Tkatchuk to Frankfurt (Oder ${ }^{28}$

Finally, in the beginning of August 1919, the Highest Entente Council declared the decision to cancel all the prohibitions regarding POWs' return of the former Russian army (approximately 200 thousand people). Its representatives left camps, and this fact had a negative impact on the position of camp inhabitants who remained there. For instance, in Salzwedel, the German garrison staff began to deprive POWs of the personal belongings which they earned with their hard work or received from Entente representatives. Consequently, Ukrainian POWs adopted a resolution during the camp gathering which pointed out Entente's inability to implement most of its responsibilities in providing POWs with enough quantity of clothes, shoes, food products and, most importantly, approving their immediate return to the motherland. Nonetheless, it played only a symbolic role because on 15 August 1919 general Malcolm informed the UNR Military and Sanitary Mission that the Entente Commission on POWs affairs had been abolished and the responsibility had been transferred to the German government ${ }^{29}$

Such decision of the Entente suspended the repatriation process due to additional complications for the German government; however, it created some favorable conditions for solving this problem. The UNR Military and Sanitary Mission and Military Ministry of Germany elaborated the itinerary for Ukrainian POWs' repatriation. The first way went from Hamburg along Danube to Odesa or Mykolaiv; the second one connected Regensburg and Brailov while the third suggested using the railway, crossing Czech and Romania. The German side agreed to provide enough number of steamships for POWs' transportation in order to use them for Germans' return from Ukraine (in case of equal expense coverage from both sides). However, these issues had to be agreed upon on the diplomatic level with the Hungarian, Czech and Romanian sides because their territories were planned to be involved. Simultaneously, the agreement with Entente states was necessary as well because they controlled the majority of German steamships ${ }^{30}$.

Yet another postponement of the evacuation dates did not affect the lifestyle of Ukrainian communities. What is more, Ukrainian POWs of 19 camps (Salzwedel, Hameln, Wetzlar, Bautzen, Sturgard, Zoltav, Celle, Frankfurt (Oder),

${ }^{27}$ Shlyah: Illustrated appendix. 14 June. 1919. Part 30; 25 June. 1919. Part 33.

28 Shlyah: Illustrated appendix. 31 December. 1919. Part 86.

${ }^{29}$ ЦДАВО України, Fond 1084 List 1 File 7 Page 322. [Central State Archive of Supreme Bodies of Power and Government of Ukraine]

${ }^{30}$ ЦДАВО України, Fond 1078 List 2 File 20 Page 138. [Central State Archive of Supreme Bodies of Power and Government of Ukraine] 
Parchim, Sagan, Muncheberg, Neuhammer, Silov Kottbus, Merzdorf Kottbus, Zerbst, Quedlinburg, Krosen, Hammelburg, Brandenburg) on 16 August 1919 organized the event of national and patriotic importance with the UNR Military and Sanitary Mission. In particular, the monument devoted to the commemoration of Ukrainians who died abroad in captivity was solemnly unveiled in Wetzlar. It was built according to the project of the famous Ukrainian artist M. Parashchuk on all POWs' donations.

According to the initiators of this event, the monument's purpose was to "remind not only the fact that 400 Ukrainian POWs lay in the Wetzlar land but also that this place was a place where, during the Great War, the Ukrainian national idea prospered" (Vidslonennya pamyatnyka 1919: 30.52; Shlyah 1919: 8.7). Among the visitors of the monument's opening, were members of the UNR Military and Sanitary Mission in Germany, including A. Zhuravel and V. Simovych as well as the member of the Ukrainian Red Cross O. Chubynskiy, employee of the UNR Embassy in Berlin B. Lepkiy and the editor of the newspaper "Shlyah" I. Moroz ${ }^{31}$

The next day after the sculpture's opening, the conference of the Ukrainian organizations' representatives of 19 POW camps in Germany took place; members of the UNR Military and Sanitary Mission led the conference. The POWs' delegates suggested uniting all the POWs in one or several camps in order to develop educational and cultural activity as well as to ease the repatriation process. In addition, they agreed to implement the Mission's control over food supplies. With the mandate of 40,000 POWs, the conference delegates adopted a special resolution with the demand for Entente countries to reconstitute the repatriation process ${ }^{32}$.

Throughout September-October 1919, the UNR Military and Sanitary Mission succeeded in transporting small groups of POWs to Czechoslovakia with further repatriation to Ukraine. Nonetheless, it was impossible to settle a largescale Ukrainians' transportation. The Mission's inquiry to the German government on 22 October 1919 asking to allow the transportation along the Danube or sea did not result in favorable consequences because this process demanded a considerable number of steamships which could not be equipped by the Military Ministry of Germany without the approval of the Entente states which, in turn, was not received.

On 4 December 1919, the council meeting of the representatives of the Military Ministry of Germany, Romanian military mission and the UNR Military and Sanitary Mission concluded with the decision to transport POWs through the territory of Romania which was accepted by its authorities. The implementation of this decision was canceled due to general Tarnavskiy's and his Ukrainian Galician Army troops' treason, with them joining Denikin's Volunteer Army. Ukrainian troops left Kamianets-Podilskyi, and the border between Ukraine and Romania was closed. Thus, only around 1000 POWs had the chance to use this way for repatriation ${ }^{33}$. Afterwards, the commission negotiated a plan with the UNR minister of foreign affairs to transport POWs through Poland, but the Mission's attempts proved to be fruitless yet another time because the Polish authorities did not approve the plan.

31 ЦДАВО України, Fond 4465 List 1 File 1024 Page 14. [Centra State Archive of Supreme Bodies of Power and Government of Ukraine]

${ }^{32}$ Shlyah: Illustrated appendix. 10 September. 1919. Part 55 (Konferenciya predstavnykiv ukrayinskykh gromad u Nimechchyni). ${ }^{33}$ ЦДАВО України, Fond 1084 List 1 File 7 Pages 323-324. [Central State Archive of Supreme Bodies of Power and Government of Ukraine]

ISSN 1728-9343 (Print)

ISSN 2411-3093 (Online)

\section{Conclusion}

The research identifies that the Mission succeeded in improving living conditions for POWs at camps through sending food supplies, clothes and shoes. In addition, it cared for POWs' moral needs by implementing courses, lessons, theatrical plays and sending Ukrainian periodicals and books to the camps. What is more, the Mission was responsible for the sanitary care, especially in regard to sending medicaments and medical staff. The mission also developed the ways and logistics of POW' repatriation process as well. The study's novelty lies in in a comprehensive research of the Mission's activity which resulted in organizing, in September-October 1919, the transportation of small POWs group to Czechoslovakia with Ukraine as a final destination. Nonetheless, the negotiations regarding a massive repatriation were not successful and, thus, a considerable part of POWs stayed in camps until May 1920. Despite these events, the Mission's activity had positive consequences for most Ukrainian POWs, particularly organizing their national life in camps.

\section{REFERENCES}

Vyedyeneyev, D., Tabachnyk, D. (1992-1993). Reprezentanty Viyska Ukrayinskoho: Storinky istoriyi viyskovoho atashatu Ukrayiny doby vyzvolnykh zmahan. Viysko Ukrayiny. Kyiv, CH.23. S.94-100 (In Ukrainian).

Vyedyenyeyev, D. (1996). Ryatuyuchy z polonu spivvitchyznykiv: $Z$ istoriyi viyskovo-sanitarnykh misiy Ukrayinskoyi Narodnoyi Respubliky. Nichna stolytsya. Kyiv, Vyp.3(3). S.6. (In Ukrainian).

Vyedyenyeyev, D. V., Budkov, D. V. (2006). Yunist ukrayinskoyi dyplomatiyi. Stanovlennya zovnishnopolitychnoyi sluzhby Ukrayiny v 1917-1923 rokakh. Monohrafiya. Kyiv, 312 s. (In Ukrainian).

Sribnyak, I. (1999a). Poloneni ukrayintsi v Avstro-Uhorshchyni ta Nimechchyni (1914-1920 rr.). Kyiv, 296 s. (In Ukrainian).

Sribnyak, I. V. (1999b). Repatriatsiyna diyalnist ukrayinskykh dyplomatychnykh i viyskovo-sanitarnykh ustanov u Yevropi v 1918 r. Studiyi z arkhivnoyi spravy ta dokumentoznavstva, t.5. Kyiv, S.259-263. (In Ukrainian).

Sribnyak, I. V. (2003). Ukrayinska Derzhava na mizhnarodniy areni: $z$ dosvidu diyalnosti voyennoyi dyplomatiyi $v 1918$ r. In: Tereshchenko Yu. I. (ed.). Hetmanskyy almanakh. Kyiv, CH.II. S.94100. (In Ukrainian).

Sribnyak, I. V. (2009). Diyalnist Dyrektoriyi UNR z repatriatsiyi polonenykh voyakiv-ukrayintsiv $z$ tereniv yevropeyskykh krayin (viyskovo-politychnyy aspekt). Kamyanets-Podilskyy - ostannya stolytsya Ukrayinskoyi Narodnoyi Respubliky: Mat-ly Vseukr. nauk. konf. Kamyanets-Podilskyy. S. 184-192. (In Ukrainian).

Sribnyak, I., Sribnyak, M. (2016). Ukrayinski viyskovo-sanitarni misiyi dlya sprav polonenykh u Nimechchyni ta Avstro-Uhorshchyni (1918-1920 rr.): stvorennya, personalnyy sklad, osnovni napryamy diyalnosti. Kyiv, $66 \mathrm{~s}$. (In Ukrainian).

Sribnyak, I., Sribniak, M. (2019a). Ukrayinska viyskovosanitarna misiya $v$ Nimechchyni y taborovi hromady polonenykh ukrayintsiv u 1919 r. Eminak: naukovyy shchokvartalnyk. KyivMykolayiv, 2(26). S.66-75. DOI: https://doi.org/10.33782/ eminak2019.2(26).292 (In Ukrainian).

Sribnyak, I., Sribniak, M. (2019b). Diyalnist Viyskovo-sanitarnoyi misiyi dlya sprav polonenykh voyakiv-ukrayintsiv u tabori Zaltsvedel, Nimechchyna (1919 - persha polovyna 1920 rr.), Visnyk Mariupolskoho derzhavnoho universytetu. Seriya: Istoriya, politolohiya. Mariupol. Vyp.24. S.114-126. (In Ukrainian).

Solovyova, V. V. (2004). Ukrayinska dyplomatiya u krayinakh tsentralnoyi Yevropy 1917-1920 rr. Donetsk. 170 s. (In Ukrainian).

Solovyova, V. V. (2006). Dyplomatychna diyalnist ukrayinskykh natsionalnykh uryadiv 1917-1921 rr. K., Donetsk. 394 s. (In Ukrainian)

Zhvanko, L.N. (1999). Evakuatsiya ta sotsialnyy zakhyst ukrayinskykh viyskovopolonenykh doby druhoho Hetmanatu (traven - hruden 1918 r.). Visnyk Kharkivskoho politekhnichnoho instytutu. Vyp. 20. S.16-27. (In Ukrainian).

SKHID No. 4 (162) July-August 2019 
Zhvanko, L. N. (2014). Ukrainskiye voyennoplennyye v gosudarstvakh Chetvortogo Soyuza: problemy vozvrashcheniya domoy (1918 god). In: Novikova, I. N., Pavlov, A. Yu., Malygina, A. A. (ed.). Pervaya mirovaya voyna, Versalskaya sistema $i$ sovremennost: sb. st. Sankt-Peterburg (Rossiya). S.94-103. (In Russian).

\section{LIST OF REFERENCE LINKS}

Вєдєнеєв Д., Табачник Д. Репрезентанти Війська Українського: Сторінки історії військового аташату України доби визвольних змагань. Військо України. 1992-1993. Ч. 2-3. С. 94-100.

Вєдєнєєв Д. Рятуючи з полону співвітчизників: 3 історії військово-санітарних місій Української Народної Республіки. Нічна столиця. К., 1996. Вип. 3 (3). С.6.

Вєдєнєєв Д. В., Будков Д. В. Юність української дипломатії. Становлення зовнішньополітичної служби України в 1917-1923 роках. Монографрія. К., 2006. 312 с.

Срібняк І. Полонені українці в Австро-Угорщині та Німеччині (1914-1920рр.). К., 1999. С. 159-203.

Срібняк І. В. Репатріаційна діяльність українських дипломатичних і військово-санітарних установ у Європі в 1918 р. Студії з архівної справи та документознавства, т.5. К., 1999. C. 259-263.

Срібняк І. В. Українська Держава на міжнародній арені: з досвіду діяльності воєнної дипломатії в 1918 р. Гетьманський альманах / відп. ред. Ю. І. Терещенко. К., 2003. Ч. II. С. 94100.

Срібняк І. В. Діяльність Директорії УНР з репатріації полонених вояків-українців з теренів європейських країн (військово-політичний аспект). Кам'янець-Подільський - остання столиця Української Народної Республіки: Мат-ли Всеукр. наук. конфр. Кам'янець-Подільський, 2009. С. 184-192.
Срібняк І., Срібняк М. Українські військово-санітарні місії для справ полонених у Німеччині та Австро-Угорщині (19181920 рр.): створення, персональний склад, основні напрями діяльності. К., 2016. 66 с.

Срібняк І., Срібняк М. Українська військово-санітарна місія в Німеччині й таборові громади полонених українців у 1919 р. Емінак: науковий щоквартальник. Київ-Миколаїв, 2019. № 2 (26). C. 66-75. DOI: https://doi.org/10.33782/eminak2019.2(26).292

Срібняк І., Срібняк М. Діяльність Військово-санітарної місії для справ полонених вояків-українців у таборі Зальцведель, Німеччина (1919 - перша половина 1920 рр.). Вісник Маріупольського державного університету. Серія: Історія, політологія. Маріуполь, 2019. Вип. 24. С. 114-126. URL: http:// elibrary.kubg.edu.ua/id/eprint/27761

Соловйова В. В. Консульська служба УНР у Центральноєвропейському регіоні. Український історичний журнал. К., 2006. № 3. C. 84-88.

Соловйова В. В. Українська дипломатія у країнах центральної Європи 1917-1920 рр. Донецьк, 2004. 170 с.

Соловйова В. В. Дипломатична діяльність українських національних урядів 1917-1921 рр. К., Донецьк, 2006. 394 с.

Жванко Л. Н. Евакуація та соціальний захист українських військовополонених доби другого Гетьманату (травень - грудень 1918 р.). Вісник Харківського політехнічного інституту. 1999. Вип. 20. С. 16-27.

Жванко Л. Н. Украинские военнопленные в государствах Четвёртого Союза: проблемы возвращения домой (1918 год). Первая мировая война, Версальская система и современность: сб. ст. / отв. ред.: И. Н. Новикова, А. Ю. Павлов, А. А. Малыгина. СПб., 2014. С. 94-103.

Кротофіл Мачей,

Університет Миколая Коперніка (м. Торунь, Польща)

e-mail:makr@umk.pl,oRCID0000-0002-6691-5532

Срібняк Ігор,

Київський університет імені Бориса Грінченка (м. Київ, Украӥна)

e-mail: i.sribniak@kubg.edu.ua,ORCID0000-0001-9750-4958

Срібняк Мілана,

Київський національний університет імені Тараса Шевченка (м. Київ, Украӥна)

e-mail: milana.sribniak@gmail.com, ORCID 0000-0003-1353-3001

\section{ДІЯЛЬНІСТЬ ВІЙСЬКОВО-САНІТАРНОї МІСІЇУНР ДЛЯ СПРАВ ПОЛОНЕНИХ У НІМЕЧЧИНІ (1919 р.)}

Актуальність статті обумовлена потребою розкриття основних аспектів діяльності Військово-санітарної місії УНР для справ полонених у Німеччині (1919р.), головним завданням якої мало стати налагодження їх репатріації. Слід відзначити, що основною перешкодою для виїзду полонених українців стало посилення деструктивних політичних процесів на теренах колишньої Російської імперії - в першу чергу в зв'язку з приходом до влади більшовиків у Петрограді. Мета студії полягає у встановленні специфіки взаємодії Місії 3 таборовими громадами полонених українців, а також обсягів та характеру гуманітарної допомоги, яка їм надавалась. Встановлено, що Місія домоглась поліпшення умов перебування полонених в таборах шляхом передачі їм продуктів харчування, одягу й взуття, а крім того вона опікувалась й духовними потребами українців, влаштовуючи в таборах курси, виклади, театральні вистави, надсилаючи до таборів українські часописи та книжки. Також Місія здійснювала й санітарну опіку полонених, надсилаючи до таборів ліки й лікарський персонал. І̆ї заходами були розроблені й маршрути та логістика процесу повернення додому полонених українців. Новизна дослідження полягає у комплексному вивченні діяльності Місії, заходами якої у вересні-жовтні 1919 р. вдалось організувати перевезення невеликих груп полонених до Чехії, звідки вони переправлялися в Україну. Але домовитись про масове переправлення полонених українців додому так і не вдалось, наслідком чого значна їх частина залишалась до травня 1920 р. Попри це діяльність Місії мала позитивні наслідки для значної кількості полонених українців, особливо для організації їх національного життя в таборах.

Ключові слова: полонені україниі; військово-санітарна місія; репатріація; табір; Антанта; Німеччина.

(c) Krotofil Maciej, Sribnyak Ihor, Sribniak Milana

Надійшла до редакції: 17.07.2019

Прийнята до друку: 12.08.2019

СХІД № 4 (162) липень-серпень 2019 р. 